\title{
CORRELATION OF BODY MASS OF SERBIAN WHITE GOAT AND TYPE OF KIDDING AND PRODUCTION TRAITS**
}

\author{
M. Žujović ${ }^{1 *}$, Z. Tomić ${ }^{1}$, M.P. Petrović ${ }^{1}$, D. Ružić Muslić ${ }^{1}$, \\ Z. Nešić ${ }^{1}$, S. Ivanović ${ }^{2}$ \\ ${ }^{1}$ Institute for Animal Husbandry, Belgrade-Zemun 1180, Serbia \\ ${ }^{1}$ National Institute of Veterinary, Belgrade, Serbia \\ *Corresponding author, e-mail: zotom@mail.com \\ **Plenary invited paper. Research financed by the Ministry of Science of Republic of Serbia, \\ Project TR 6858
}

\begin{abstract}
Main breeding objective in improvement of goat production is realization of increase of number of animals and production and creation of constant highly productive goat breeding on private farms of individual producers. For economically efficient goat production, size and number of goats in the herd are of great importance. Considering that goats of greater body mass should realize higher production, body mass of head can serve as one of the parameters in selection. Objective of this research was to determine optimal body masses of heads in population of Serbian White goat, in hilly-mountainous region of Stara Planina Mountain, in semiintensive rearing system (pasture-stable) and in relation to realized production. Based on results of research it can be concluded that optimal body mass of investigated heads in population of Serbian White goat in regard to observed parameters of production is between $40-47 \mathrm{~kg}$.
\end{abstract}

Key words: production traits, body mass, population of Serbian White goat, pregnancy, lactation, milk.

\section{Introduction}

Intensive goat production is based mainly on genetic potential and goat life cycle with application of modern technological and technical solutions. For economically efficient goat production, size and number of goats in the herd are of great importance. Experiences indicate that size of goat can influence not only the investment value, but also the value of realized production. It is a fact that goats with greater body mass should have higher production, and that body mass of heads can be used in selection on other 
traits. If it is certain that increase of body mass in goats has as a consequence, among other things, considerable increase of feed consumption, than the need for determination of optimal body mass of goats is imposed, in order to realize economically efficient production primarily of milk, and by increased fertility also of meat.

Lately, much attention is directed to this issue. However, very little attention and significance in our country has been directed to this problem, therefore objective of our research was to determine the optimal body mass in population of Serbian White goat in hilly-mountainous region of Stara Planina Mountain, in semi-intensive rearing system (pasture-stable) in relation to realized production.

\section{Material and methods}

In this research population of Serbian White goat was used reared in the region of Stara Planina Mountain by individual farmers. Semi-intensive rearing system is used, pasture-stable at the age of goats of 4,5 years, in the third lactation, full physiological growth. Goats were divided into two groups, those which gave birth to single kids - 176 heads and those which gave birth to twins - 135 heads, goats with three or four kids weren't considered because of small number of such heads.

All investigated heads were in the same housing, nutrition and conditions relating to their care through entire investigation period. In both groups of goats, duration of pregnancy was calculated based on dates of mating and partus, body mass of goats and kids at birth and weaning at the age of 120 days were measured using weighing scale, also average daily gain of kids for investigated period was calculated. Milk controls of goats in third lactation were done once a month, manually and with $2000 \mathrm{ccm}$ measuring vessel, and than average daily quantities of milk and duration of lactation determined. All collected data were processed systematically using standard statistical methods, including correlation coefficients of body mass to all investigated traits.

\section{Results and Discussion}

Average results relating to duration of pregnancy, mass of kids at birth and weaning, as well as gain before weaning according to sexes, also average daily amount of milk in lactation and duration of lactation in goats which gave birth to single kids and twins are presented in table 1 , and 
Table 1. Body mass of Serbian White goat according to production traits

\begin{tabular}{|c|c|c|c|c|c|c|c|c|c|c|c|c|c|c|}
\hline \multirow[t]{2}{*}{ Traits } & \multirow{2}{*}{$\begin{array}{c}\mathrm{POL} / \mathrm{S} \\
\text { eh }\end{array}$} & \multicolumn{13}{|c|}{ Body mass } \\
\hline & & 36 & 38 & 40 & 42 & 44 & 46 & 48 & 50 & 52 & 54 & 56 & 58 & 60 \\
\hline \multicolumn{15}{|c|}{ Ovce sa jedincima/Sheep with single lamb $(n=176)$} \\
\hline Duration of pregnancy (days) & & 154,5 & 152,6 & 158,3 & 151,7 & 156,4 & 150,7 & 150,5 & 154,3 & 153,4 & 153,7 & 149,6 & 153,2 & 151,0 \\
\hline \multirow[t]{2}{*}{ Body mass at (kg) } & 0 & 3,6 & 3,5 & 3,7 & 3,6 & 3,9 & 3,7 & 3,7 & 3,7 & 3,8 & 4,0 & 3,4 & 4,1 & 4,2 \\
\hline & 우 & 3,7 & 4,1 & 4,2 & 4,2 & 3,8 & 4,0 & 3,8 & 4,7 & 3,8 & 4,0 & 4,3 & 4,2 & 4,2 \\
\hline \multirow[t]{2}{*}{ Body mass at weaning $(\mathrm{kg}$} & $\sigma^{\pi}$ & 26,1 & 28,2 & 29,9 & 29,7 & 30,2 & 32,3 & 32,6 & 32,4 & 34,4 & - & 34,1 & 34,9 & 36,0 \\
\hline & 우 & 27,7 & 28,0 & 30,7 & 30,7 & 31,8 & 32,8 & 34,3 & 34,1 & 35,1 & 34,7 & 39,8 & 39,5 & 38,9 \\
\hline \multirow[t]{2}{*}{ Gain prior to weaning $(\mathrm{g})$} & $0^{\pi}$ & 212 & 207 & 214 & 226 & 237 & 263 & 232 & 242 & 283 & - & 229 & 240 & 347 \\
\hline & q & 254 & 208 & 207 & 218 & 194 & 246 & 223 & 248 & 241 & 233 & 290 & 319 & 206 \\
\hline Average duration of lactation (days ) & & 253,9 & 534,0 & 254,3 & 258,7 & 260,5 & 261,9 & 261,9 & 261,9 & 263,1 & 263,9 & 267,5 & 269,0 & 269,1 \\
\hline Milk quantity $\left(\mathrm{cm}^{3}\right)$ & & 1,676 & 1,350 & 1,637 & 1,662 & 1,695 & 1,659 & 1,645 & 1,630 & 1,716 & 1,687 & 1,888 & 1,683 & 1,762 \\
\hline \multicolumn{15}{|c|}{ Goats with twin kids $(\mathrm{n}=135)$} \\
\hline Duration of pregnancy (days) & & 155,6 & 152,5 & 157,3 & 157,7 & 1537 & 156,8 & 153,8 & 148,6 & 149,8 & 150,5 & 150,5 & 153,5 & 152,1 \\
\hline \multirow[t]{2}{*}{ Body mass at lambing $(\mathrm{kg})$} & $0^{\lambda}$ & 3,4 & 3,5 & 3,5 & 3,4 & 3,7 & 3,6 & 3,5 & 3,6 & 3,7 & 3,5 & 3,8 & 3,4 & 3,5 \\
\hline & & 3,8 & 3,5 & 3,7 & 3,8 & 4,2 & 3,9 & 3,8 & 3,9 & 3,7 & 3,8 & 3,6 & 3,5 & 3,6 \\
\hline \multirow[t]{2}{*}{ Body mass at weaning $(\mathrm{kg})$} & $\hat{\sigma}$ & 26,6 & 25,0 & 30,5 & 28,0 & 30,1 & 30,4 & 27,3 & 31,2 & 32,2 & 32,1 & 33,7 & 29,3 & 31,3 \\
\hline & o & 28,4 & 29,0 & 34,2 & 30,6 & 32,5 & 32,8 & 32,3 & 32,5 & 34,3 & 34,7 & 32,9 & 32,0 & 33,2 \\
\hline \multirow[t]{2}{*}{ Gain prior to weaning (g) } & $\sigma^{\lambda}$ & 189 & 179 & 237 & 239 & 219 & 200 & 206 & 278 & 245 & 220 & 239 & 176 & 239 \\
\hline & 우 & 196 & 204 & 240 & 221 & 289 & 258 & 233 & 236 & 257 & 271 & 256 & 237 & 267 \\
\hline Average duration of lactation (days ) & & 269,5 & 269,8 & 271,1 & 272,2 & 272,8 & 273,4 & 274,5 & 278,0 & 278,6 & 279,3 & 282,0 & 284,2 & 288,5 \\
\hline Milk quantity $\left(\mathrm{cm}^{3}\right)$ & & 1,646 & 1,628 & 1,746 & 1,674 & 1,579 & 1,706 & 1,752 & 1,607 & 1,542 & 1,780 & 1,743 & 1,683 & 1,616 \\
\hline
\end{tabular}


correlation coefficients (r) between body mass and investigated traits in table 2 .

Our results indicate the connection between body mass of goats and duration of pregnancy. Although this connection is distinct in both groups of goat with low correlation coefficient, is also very weak and negative, and not statistically significant $(\mathrm{P}>0,05)$. However, it enabled pointing out the tendency of decrease of duration of pregnancy with the increase of body mass, which is more obvious in goats which gave birth to twins. Optimal body mass for shorter duration of pregnancy is $46 \mathrm{~kg}$ in goats which gave birth to single kids and $50 \mathrm{~kg}$ for goats with twin kids.

The relation of body mass of goat-dams to body masses of their kids at birth varies depending on the sex of kids, and between dams which gave birth to single and twin kids. Analysis of correlation coefficients indicates positive, but low correlation between body mass of goats and male kids, so it can almost be said that it doesn't exist, not is it statistically significant $(\mathrm{P}>0,05)$. In female kids, it is positive, but medium and statistically very significant $(\mathrm{P}<0,01)$.

Table 2. Correlation of body mass of Serbian White goat according to type of kidding and production traits

\begin{tabular}{|l|c|c|}
\hline Groups & Single kids & Twins \\
\hline Duration of pregnancy (days) & $-0,1243^{\mathrm{NS}}$ & $-0,1769^{\mathrm{NS}}$ \\
\hline Body mass of kids at birth & & \\
\hline Female & $0,4170^{* *}$ & $0,0706^{\mathrm{NS}}$ \\
\hline Male & $0,0233^{\mathrm{NS}}$ & $9,0733^{\mathrm{NS}}$ \\
\hline Body mass of kids at weaning & & $-0,3125^{\mathrm{NS}}$ \\
\hline Female & $0,8118^{* *}$ & $0,2241^{\mathrm{NS}}$ \\
\hline Male & $0,4066^{* *}$ & \\
\hline Daily gain from birth to weaning & & $-0,2029^{\mathrm{NS}}$ \\
\hline Female & $0,5048^{* *}$ & $0,0039^{\mathrm{NS}}$ \\
\hline Male & $0,4519^{* *}$ & $-0,1627^{\mathrm{NS}}$ \\
\hline Quantity of milk & $0,0382^{\mathrm{NS}}$ & \\
\hline
\end{tabular}

** Statistically very significant $(\mathrm{P}<0,01) *$ statistically significant $(\mathrm{P}<0,05){ }^{\mathrm{ns}}$ statistically not significant $(\mathrm{P}>0,05)$

In production of kid meat significant is the effect of body mass of goatdam on occurrence of twins, body mass and gain of kids to weaning. In our research we determined that the increase of incidence of twins is related to body mass and increases with growth of body mass. Considering that birth of twins is regarded as one of the significant factors of increase of meat 
production, importance of body mass would be significant also for production of twins. However, according to our results, the effect of body mass of dam on mass of kids at birth was mainly insignificant in males but very distinct in female kids. Thanks to very small variations of our results, it can be concluded that, in relation to mass at birth, optimal mass for single kids of both sexes would be $38-40 \mathrm{~kg}$. However, in twins, according to our results, this range for both sexes was $42-44 \mathrm{~kg}$.

The effect of body mass of dams was considerably higher on body mass at weaning, and for gain to weaning, slightly higher in case of female kids. This is confirmed by positive, very strong and significant $(\mathrm{P}<0,01)$ correlations. More distinct increase of body masses of female kids starts with body masses of dams of $46 \mathrm{~kg}$, and of male kids with dams' body masses of $48 \mathrm{~kg}$, after which further increase of kid masses is not significant. However, in case of twins the situation is different, since dependence on dams' body masses is lower than in case of singles, and in male kids weak correlation without statistical significance was established $(\mathrm{P}>0,05)$, whereas in case of female kids correlation was weak and negative and also without statistical significance $(\mathrm{P}>0,05)$. In both groups of twins, $46 \mathrm{~kg}$ was limit body mass which was body mass from which increase of kids body mass started. This is related to production of milk, which in case of twins had greater significance for growth till weaning than body mass of dams, since gain of kids depends on milk quantity, and probably the importance of body mass of dams in this case is hidden. However, body mass of dams is fully expressed in case of single kids where quantity of milk for rearing of kids is not important. It is important to emphasize that situation regarding body mass to weaning, as well as gain in this period, were in accordance with realized correlations for milk yield, duration of lactation and body mass of goats.

In regard to average daily gain of kids to weaning, we established that gain of male and female single kids increased convincingly with the increase of dams' body masses. This increase is even more distinct starting with 46 $\mathrm{kg}$, and with further increase of the body mass of dams increase in gain of single kids remains more or less stable, with slight tendency of increase. Accordingly, the body mass of dam of $46 \mathrm{~kg}$ would be adequate/suitable for maximal gain of single kids of both sexes.

It is characteristic, also, that maximal gain twin kids of both sexes realize already in cases when body mass of their dams was $40 \mathrm{~kg}$, and maintaining this level.

Confirmation of the mutual connection between body mass of dam and daily gain of single kids to weaning are correlation coefficients, positive for 
dams with single kids. These correlations are medium strong and statistically very significant $(\mathrm{P}<0,01)$. However, correlations in case of twin kids are slight, therefore non-existing and without statistical significance.

By analyzing results relating to average duration of lactation and average daily milk yield of Serbian White goat in third lactation according to their body masses, it can not be concluded that there is some explicit/distinct regularity, especially in case of goats which gave birth to single kids. Lighter goats, which gave birth to twin kids, had slightly more milk. However, variation of milk yield is very explicit, as well as average duration of lactation, so it can be concluded that quantity of milk, obtained from goats which gave birth to single kids with $42 \mathrm{~kg}$, and of goats which gave birth to twin kids with body mass of $40 \mathrm{~kg}$, can be considered as satisfactory. In both groups of goats such milk production is demonstrated by correlation coefficients. Correlation coefficients in goats with single kids are positive, but so small almost non-existing, whereas in case of goats with twin kids negative but very weak. These correlations are not statistically significant $(\mathrm{P}>0,05)$.

In regard to duration of lactation in goats which gave birth to single kids, it increases starting from body mass of $36 \mathrm{~kg}$ constantly to $60 \mathrm{~kg}$, and in goats which gave birth to twin kids, the trend of increase was similar to values obtained for goats with single kids. Correlation between body masses of goats and duration of lactation in both investigation groups was positive and in goats with twin kids slightly more expressed, but in both groups weak and without statistical significance $(\mathrm{P}>0,05)$.

Relying on the obtained results and their analysis we established that average body mass of all investigated goats in population of Serbian White goat was $46.9 \mathrm{~kg}$ and completely satisfies optimal goat production in this population.

In domestic literature as well as international, only few papers investigated the correlation between body mass of goats and their production traits. According to available literature similar results were obtained by Žujović (1988, 1993), Žujović et al.,(1991, 1992, 1993a, 1995, 1995a, 2002 and 2003) results relating to Domestic White goat and Saanen goat, Žujović et al., (2006) and for Alpine breed reared in the region of Stara Planina Mountain and Žujović et al., (2006a) for Serbian White goat. Also, Marković (1997) published results relating to Domestic Balkan goat reared in Montenegro and Memiši (2000), Memiši et al., (1998) to Balkan goat breed, Mukherjee et al., (1982) to Indian Gray Bengal goat, Prasad et al., (1981) to Indian Black Bengal goat, Manik et al., (1984) to Indian Betal goat and its 
crosses with Alpine and Saanen goat, and Bose et al., (1984) to Indian Betal goat. Our results and conclusions are in accordance with results of stated authors.

\title{
Conclusion
}

Based on analysis of obtained results of body mass of Serbian White goat population in relation to duration of pregnancy, duration of third lactation, average daily milk quantity, birth of twins, body mass of kids at birth and weaning, and gain to weaning, the following can be concluded:

- Optimal body mass of goats of Serbian White population was 46,9 $\mathrm{kg}$ and fully satisfies optimal production of milk and meat.

- Optimal body mass of goats for production of milk is $40,0 \mathrm{~kg}$.

- Optimal body mass of goats for production of meat, considered through incidence of twin kids, body mass of kids to weaning and gain of offspring $46,0 \mathrm{~kg}$.

By analyzing stated results for investigated traits of population of Serbian White goat it can be concluded that optimal body mass of investigated heads in relation to observed parameters, production of milk and meat is from 40,0 - 47,0 kg. These results are based on relatively greater number of goats reared by individual breeders and they enabled previously mentioned results.

\section{KORELACIONA POVEZANOST TELESNE MASE SRPSKE BELE KOZE PREMA TIPU JARENJA I PROIZVODNIM OSOBINAMA}

\author{
M. Žujović, Z. Tomić, M.P. Petrović, D. Ružić Muslić, Z. Nešić, \\ S. Ivanović
}

\section{Rezime}

Osnovni odgajivački cilj u poboljšanju kozarske proizvodnje je povećanje broja životinja i povećanje proizvodnje, odnosno stvaranje stalnog visokoproduktivnog kozarstva na farmama individualnih odgajivača. Za ekonomičnu kozarsku proizvodnju od velike važnosti je veličina grla i 
brojnost koza u stadu. Polazeći od činjenice da koze sa većom telesnom masom treba da ostvare i veću proizvodnju, to masa tela grla može da posluži i kao jedan od parametara u selekciji. Cilj ovih istaživanja je da se utvrde optimalne telesne mase grla u populaciji srpske bele koze, u brdskoplaninskom području Stare Planine, u poluintenzivnom sistemu gajenja (pašno-stajski) i u odnosu na ostvarenu proizvodnju. Na osnovu rezultata sprovedenih istraživanja može se zaključiti da je optimalna telesna masa ispitivanih grla $\mathrm{u}$ populaciji srpske bele koze $\mathrm{u}$ odnosu na posmatrane parametre proizvodnje izmedju $40-47 \mathrm{~kg}$.

Ključne reči: proizvodne osobine, telesna masa, populacija srpske bele koze, bremenitost, laktacija, mleko.

\section{References}

BOSE, S; BASU, S.B, (1984): Relationship between body measurements and meat production in Beetal goats. Indian Veterinary Journal, National Dairy Research Institute, Karnal Haryana India.61 (7), 670-673.

MANIK, R.S, PATIL, R.A, TOMER, O.S, (1984): Production of body veight from body measurements in Beetal goats and their crosses with Alpine and Saanen. Livastock Adviser, National Dairy Resarch Institute, Kalkuta, Haryana, India. 9 (4), 33-36.

MARKOVIĆ B. (1997): Proizvodne i reproduktivne osobine važnijih varijeteta domaće balkanske koze u Crnoj Gori. Magistarski rad. Univerzitet u Beogradu. Poljoprivredni fakultet, Zemun. 1-90

MEMIŠI, N., BOŽOVIĆ, V., BAUMAN F., LATINOVIĆ, D., (1998): Fenotipska varijabilnost osobina mlečnosti i telesne razvijenosti Balkanske rase koza. Savremena poljoprivreda, Novi Sad.Vol. 47 (5-6), 109-114.

MEMIŠI, N., (2000): Kvantitativna analiza telesne razvijenosti i proizvodnih osobina domaće balkanske koze. Doktorska disertacija.Univerzitet u Beogradu. Poljoprivredni fakultet, Zemun. 1-161.

MUKHERJEE, K.D, SINGH, C.S.P, MICHRA, H.R, NATH, S, (1982): Comparations of correlations between body wight and body measurements in Grey and Brown Bemgal goats. Indian Veterinary Medical Journal, Animal Breeding Departement, Ranchi Veterinary College, Ranchi, Bihar, India. 6 (1), 44-47.

PRASAD, B., SINGH, C.S.P, MICHRA, H.R, (1981): Note on body weight measurements relationship in Black Bengal goats. Indian Journal of Animal Sciences, Animal Breeding Departement, Ranchi Veterinary College, 
Ranchi, Bihar, India.Vol. 51 (9), 880-882.

ŽUJOVIĆ, M. (1988): Oplemenjivanje populacije koza gajenih na farmi „Bačevsko polje“ u Dimitrovgradu. Magistarski rad.Univerzitet u Beogradu. Poljoprivredin fakultet, Zemun. 3-141.

ŽUJOVIĆ, M., ŽUJOVIĆ MIROSLAVA, STOJKOVIĆ, M., (1991): Korelaciona povezanost mase tela i nekih telesnih mera domaće bele koze i njenih meleza sa Sanskom. I Interrnational Summer Conference for Advancement of Sheep and Goat Production, Ohrid, Macedonia. 263-268.

ŽUJOVIĆ, M., PETROVIĆ, M.M., ŽUJOVIĆ MIROSLAVA, MIŠČEVIĆ, B., (1992): Primena linearnih metoda u ocenjivanju priplodne vrednosti jarčeva različitih genotipova. Medjunarodni Simpozijum „Stočarstvo na pragu XXI veka“. Biotehnologija u stočarstvu, Vol. 8 (5-6), 151-158.

ŽUJOVIĆ, M., (1993): Proizvodnja i osobine mleka domaće bele koze. Doktorska disertacija. Univerzitet u Novom Sadu. Poljoprivredni fakultet, Novi Sad. 3-150.

ŽUJOVIĆ, M., ŽUJOVIĆ MIROSLAVA (1993a): Fenotipske korelacije izmedju mase tela i nekih telesnih mera u tri genotipa koza. Savremnena poljoprivreda, Seminar o savremenoj stočarskoj proizvodnji, Novi Sad.1-2, 128-130,

ŽUJOVIĆ, M., KRAJINOVIĆ, M., PETROVIĆ, M.P., STOJKOVIĆ, M., BAUMAN F. (1995): Domestic white goat reproduction abilities as precondition for the goat breeding production increase. $3^{\text {th }}$ International conference of sheep and goat production. Proceeding Ohrid, Macedonija. 209-218.

ŽUJOVIĆ, M., PETROVIĆ P.M., (1995a): Milk production of Domestic white goat and her $F_{1}$ generation crosses Saneen goat from Bulgaria. IV International sympisium „New Trends in Developement of Animal Husbandry, Belgrade Biotechnology in animal husbandry, Vol. 11 (7-8), Institute for animal husbandry, Belgrade-Zemun. 129-134.

ŽUJOVIĆ, M., PETROVIĆ, P.M., TOMIĆ Z., CMILJANIĆ, R., TOMAŠEVIĆ D., STRSOGLAVEC S., MEMIŠI, N., (2002): Uticaj ranog odlučivanja jaradi blizanaca na njihov razvoj i proizvodnju mleka i mesa. Biotehnologija u stočarstvu, Vol. 18 (5-6), 81-85.

ŽUJOVIĆ, M., JOSIPOVIĆ, S., TOMIĆ Z., CMILJANIĆ, R., PETROVIĆ, P.M., NEŠIĆ Z., LUKIĆ, M., MRFAT-VUKELIĆ S. (2003): Determinationof the optimal body weight of Domestic white goat according to production performance. $7^{\text {th }}$ International symposium „Modern Trends in Livestock Production“. Biotehnology in Animal Husbandry, Vol. 19 (5-6), 149-153. 
ŽUJOVIĆ, M., TOMIĆ Z., PETROVIĆ P.M., RUŽIĆ-MUSLIĆ D., STOJANOVIĆ LJ. (2006): Qvantity and quality milk from Alpine breed goat in lactasion, acclimatized to contitions on Stara Planina mountain. The $3^{\text {th }}$ InternationalSession of SCientific Communications the Scentific papers of Faculty of Animal Science, Bucharest, Romania. 283-288.

ŽUJOVIĆ, M., TOMIĆ Z., PETROVIĆ, P.M., RUŽIĆ-MUSLIĆ D., STOJANOVIĆ LJ. (2006a): Quality of milk from Serbian white goat in first lactation. Biotehnology in animal husbandry. Vol. 22 (5-6), 63-70. 